\title{
舌喉頭矯正術による下咽頭の拡大
}

\author{
新田 暢圭・向井 將・向井千珈子*

\section{Locational Changes between Hyoid Bone and Cranium after Correction of Glosso-Larynx (CGL)}

\author{
Masayoshi Nitta, Susumu Mukai and Chikako Mukai \\ (Mukai Clinic and Mukai Research Institute of Biology)
}

\begin{abstract}
CGL was performed on thirty adults who complained of sleep disorder. We studied the following six items by head and neck X-ray before and after CGL. The results are shown parentheses at the end of each item.

1) The shortest vertical length between the hyoid bone and mandible $(+10.3 \mathrm{~mm})$

2) Vertical length between the hyoid bone and the tangent of $\mathrm{C} 2-4(+4.6 \mathrm{~mm})$

3) The shortest length between the hyoid bone and the chin $(+2.9 \mathrm{~mm})$

4) The angle of the hyoid bone and the tangent of $\mathrm{C} 2-4$ ( +3.3 degrees)

5) The length of $\mathrm{H}-\mathrm{M}$ ( $\mathrm{H}$ is an intersection of a tangent of $\mathrm{C} 2-4$, vertical from the hyoid bone. $\mathrm{M}$ is an intersection of a tangent of $\mathrm{C} 2-4$ and mandibular.) $(+7.4 \mathrm{~mm})$

6) Width of the narrowest part of the hypopharynx $(+3.0 \mathrm{~mm})$

Every items showed a significant difference between before and after the CGL, $(p<0.05)$.

After the operation, the hyoid bone moved downward and the cranial bone rotated forward. As a result, the hypopharynx and the oropharynx expanded. Expansion of the hypopharynx calculated that the resistance of flow decreased, whereas the airflow increase.
\end{abstract}

Key words : hyoid bone, CGL, sleep disorder, hypopharynx, airflow

はじめに

睡眠障害症状は新生児・乳児から大人まで一連のもの である．その症状の表現形態が異なっているにすぎない． 新生児・乳児の症状は眠りが浅い, 抱さ癖, 疳泣など. 幼小児では寝相が悪い，寝起きが悪い，斯をかく，成人 では斯, 昼間の眠さ, 疲労感などである.これらの症状 は舌・喉頭矯正術 (CGL : Correction of Glosso-Larynx) により改善される.さらにCGL 手術後に睡眠時無呼吸 の減少, 動脈血酸素飽和度の上昇, 肺活量の増加, 一秒 率の増加や，前記した睡眠障害の諸症状の改善について は報告した1) 6).

今回われわれは CGL 前後の舌骨と頭蓋(特に下頸骨)
との相対的な位置の変化を頭部単純X線で比較し，舌体 は願舌筋突起を支点として前下方へ移動し下咽頭が拡大 することを再確認したので報告する.

\section{方法}

対象は向井診療所を1997年 6 ～12月に受診した舌・喉 頭偏位症 (ADEL : Ankyloglossia with Deviation of the Epiglottis and Larynx) の症状1) 7) を城人30名(男性 15名, 女性 15 名), 平均年齢は 30.0 歳であった. 全員の CGL 前後(術式については考察を参照) 飞単純頭頸部側 面X線写真撮影を次のような条件で行った。焦点距離は 各人で一定になるように調節，管電圧 $58 \sim 63 \mathrm{kV}$ ，管電 
流 $200 \mathrm{~mA}$ ，照射時間 $0.06 \sim 0.1$ 秒，フィルム面までの 距離 $800 \mathrm{~mm}$. 撮影時に被検者は座位で正面を向くよう に指示し, 頭部の左右への傾きと回転の制限は固定し, 開口・曣下・発声は禁止した ${ }^{899)}$. 術前の撮影は術前検 査の際 (手術前 1 カ月以内) に, 術後は手術直後ないしは 術後 1 日目に行った.

測定部位

上記条件で撮影した頭部単純 $\mathrm{X}$ 線写真上で以下の部位 を測定比較した(図 1 )。

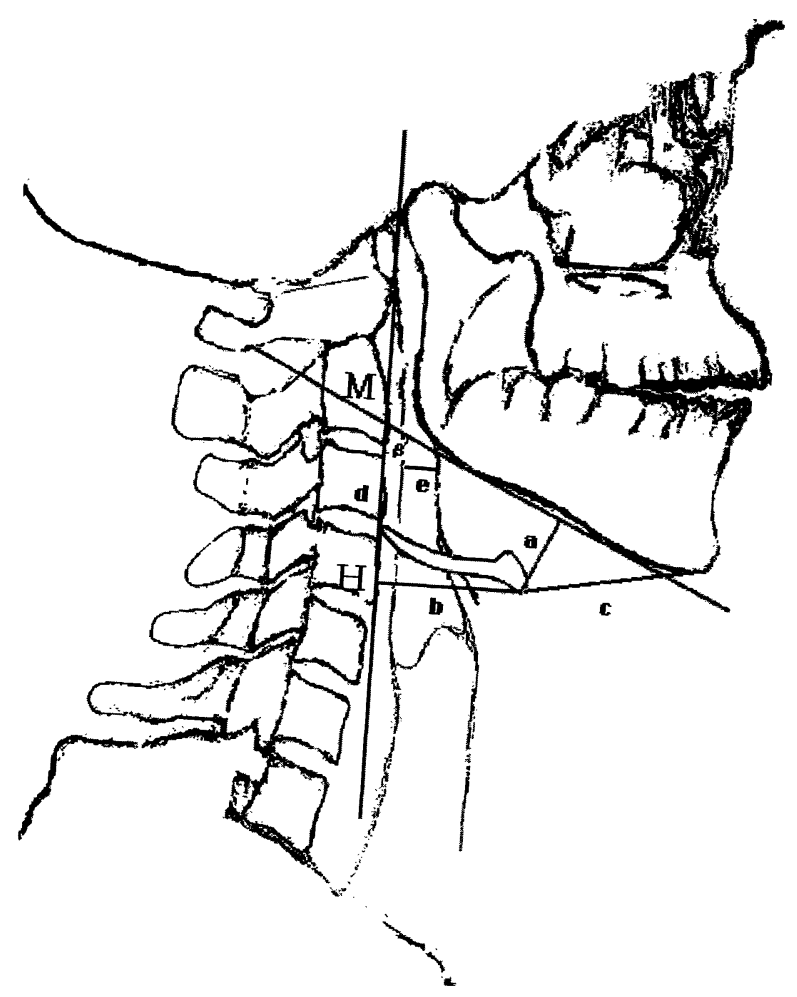

図 1 頭部単純 $\mathrm{X}$ 線写真による測定部位(コンピュータにより 輪郭検出）
1 ）舌骨体部尖端と下靧骨体部下端の接線の最短垂直 距離 (a)

2 ) 舌骨体部尖端と椎骨 (C2-4) 接線の垂直距離 (b)

3 ) 舌骨体部尖端と下買骨体部尖端(頋部)の距離 (c)

4 ) 椎骨 (C2-4) 接線に対する下靧骨体部下端接線の 角度 $(\beta)$

5 ) 距離 H-M (d)

(点H : 椎骨 (C2-4) 接線と舌骨体部尖端からの垂線の交点) （点 $M$ : 椎骨 (C2-4) 接線 と下買骨体部下端接線の交点） 6 ) 下咽頭最狭部巾 (e)

計測には $1 / 100 \mathrm{~mm}$ まで計測可能な精密ノギスを用い， 小数点第二位は四捨五入した. 結果の検定には Stat View（統計ソフト)を使用した.

\section{結＼cjkstart果（表 1)}

1 ) 舌骨体部尖端と下䫇骨体部下端の接線の最短垂直 距離 (a) は術後に平均 $10.3 \mathrm{~mm}$ 増兄ていた。術前後に は高度の有意差がみられた $(\mathrm{p}<0.001)$.

2 ) 舌骨体部尖端と椎骨 (C2-4) 接線の垂直距離 (b) は 術後に平均 $4.6 \mathrm{~mm}$ 増加していた。術前後には高度の有 意差がみられた $(\mathrm{p}<0.001)$.

3 ) 舌骨体部尖端と下罘骨体部尖端(眞部)の距離 (c) は平均 $2.9 \mathrm{~mm}$ 延びていた. 術前後には有意差がみられ た $(\mathrm{p}<0.005)$.

4 ) 椎骨 (C2-4) 接線に対する下䫁骨体部下端接線の 角度 $(\beta)$ は平均 3.3 度増加していた。両者には高度の有 意差が認められた $(\mathrm{p}<0.005)$.

5 ）距離 $\mathrm{H}-\mathrm{M}$ (d) は $7.4 \mathrm{~mm}$ 增加していた。術前後 には高度の有意差がみられた $(\mathrm{p}<0.001)$.

6) 下咽頭最狭部巾 (e) は術前平均 $12.6 \mathrm{~mm}$, 術後平 均 $15.6 \mathrm{~mm}$ で術後には $3.0 \mathrm{~mm}$ 広がっていた。両者に は高度の有意差がみられた $(\mathrm{p}<0.001)$.

表 1 測定結果

\begin{tabular}{|c|c|c|c|c|c|c|c|c|}
\hline 測 & 定 & 部 & 術前 & （標準偏差） & 術後 & （標準偏差） & 変化值 & $\mathrm{t}$ 検定 : $\mathrm{p}$ 值 \\
\hline \multicolumn{3}{|c|}{ 舌骨と下顎骨の接線の最短垂直距離 ( a ) } & $7.7 \mathrm{~mm}$ & $5.3 \mathrm{~mm}$ & $18.0 \mathrm{~mm}$ & $3.9 \mathrm{~mm}$ & 10.3 & $\mathrm{p}<0.001$ \\
\hline \multicolumn{3}{|c|}{ 舌骨と椎骨 (C2-4) 接線の垂直距離 ( b ) } & $40.1 \mathrm{~mm}$ & $4.1 \mathrm{~mm}$ & $44.7 \mathrm{~mm}$ & $5.0 \mathrm{~mm}$ & 4.6 & $\mathrm{p}<0.001$ \\
\hline \multicolumn{3}{|c|}{ 舌骨と下頧骨尖端(頋部)の距離 ( c ) } & $52.5 \mathrm{~mm}$ & $6.2 \mathrm{~mm}$ & $55.4 \mathrm{~mm}$ & $4.9 \mathrm{~mm}$ & 2.9 & $\mathrm{p}<0.005$ \\
\hline \multicolumn{3}{|c|}{ 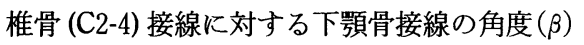 } & 69.3 度 & 5.3 度 & 72.6 度 & 5.2 度 & 3.3 & $\mathrm{p}<0.005$ \\
\hline \multicolumn{3}{|l|}{ 距離 H-M (d ) } & $23.3 \mathrm{~mm}$ & $8.5 \mathrm{~mm}$ & $30.7 \mathrm{~mm}$ & $7.8 \mathrm{~mm}$ & 7.4 & $\mathrm{p}<0.001$ \\
\hline \multicolumn{3}{|c|}{ 下咽頭最狭部巾 (e ) } & $12.6 \mathrm{~mm}$ & $0.4 \mathrm{~mm}$ & $15.6 \mathrm{~mm}$ & $4.9 \mathrm{~mm}$ & 3.0 & $\mathrm{p}<0.001$ \\
\hline
\end{tabular}




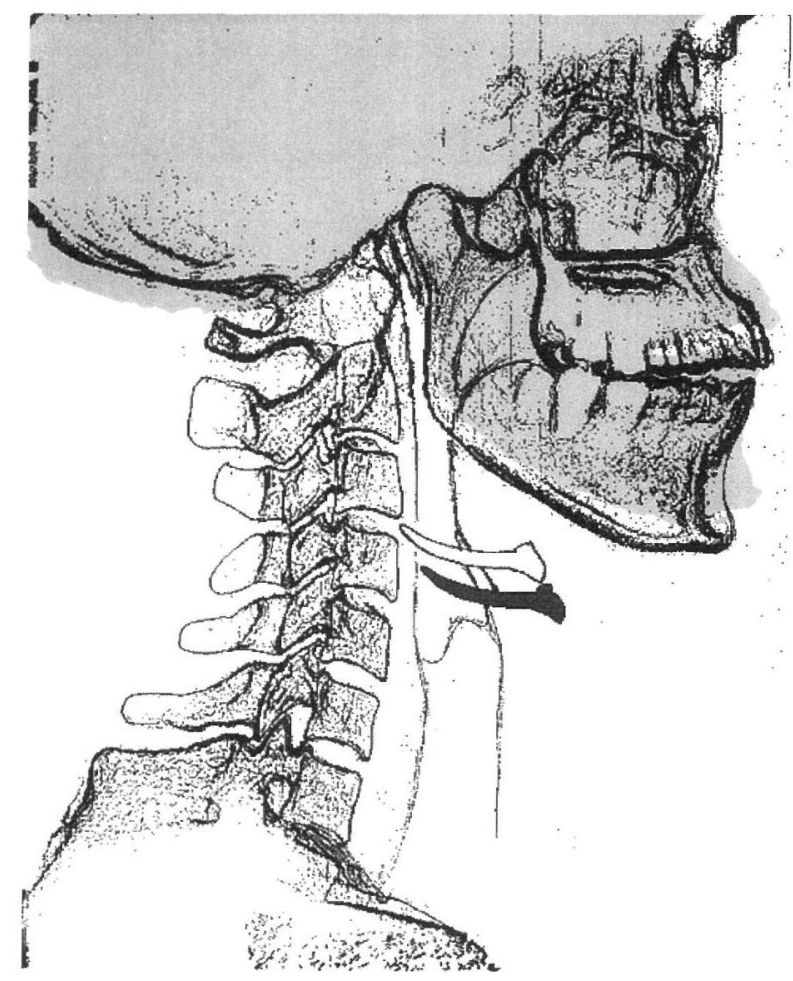

図 2 術前(輪郭の夕) と術後(陰影部分)の舌骨体部尖端と頭蓋 の変化の平均值を入力, コンピニータにより合成(下顎 が上方へ向き，舌骨が下前方へ移動している.).

上記結果を総合すると, 舌骨体部尖端は下・前方に移 動していた．委た下顎は挙上し，また下咽頭巾は広がっ ていた.この結果は, 舌中隔・願舌筋一部切断により, 舌全体が下顎尖端・願舌筋付着部を支点として下前方へ 回転し下咽頭が広がったことを示している(図 2，3）。

\section{考察}

1996年にわれわれは舌骨，喉頭，喉頭蓋，下顎下縁を 椎弓 (C2-4) を基準として舌・喉頭矯正術による変化を 計測して次のような結果を得た。すなわち, 舌骨ならび に喉頭は下がり，頭蓋が幾分上がり，下顎が上方に回転 した。をた喉頭蓋はより直立し，下咽頭が広くなってい た.この計測結果は舌体の力が喉頭, 下顎骨, 頭蓋飞掛 かっていることを示していた10)。交た下咽頭最狭部の巾 は2.3 mm 広がっていた(今回の母集団では $3.0 \mathrm{~mm}$ ). この検索に执いては各部の位置の変化は判明したが，そ の位置の変化で何故下咽頭巾が広がったかが不明であっ た。

今回の検索では頭蓋骨と舌骨の相対的位置関係の変化
を調べた。その結果 1 ) 舌骨体部尖端と下買骨体部下端 の接線の最短垂直距離 (a) は術後に平均 $10.3 \mathrm{~mm}$ 増光 て, 2 ) 舌骨体部尖端之椎骨 (C2-4) 接線の垂直距離 (b) は術後に平均 $4.6 \mathrm{~mm}$ 増加し, 3 ) 舌骨体部尖端之下顎 骨体部尖端 (頣部)の距離 (c) は平均 $2.9 \mathrm{~mm}$ 延びていた。 末た 5 ) 距離 H-M (d) 4 ) 椎骨 (C2-4) 接線に対する下顎骨体部下端接線の角度 (ア)は平均3.3度増加していた。 これは顎が幾分上がった ことを示している. 以上の変化は, 舌体が下顎尖端内側 の願舌筋付着部(願舌筋突起) を支点として下前方へ回転 したことを意味している。皇の結果 6 )下咽頭最狭部巾 (e) は術後には $3.0 \mathrm{~mm}$ 広がっていた ${ }^{11)}$. 今回の計測に より頭蓋・舌骨などの相対的位置の变化が下咽頭の拡大 をもたらすことが判明した。

舌・喉頭矯正術 (CGL) は願舌筋の筋層を $1 \sim 3$ 層切 断するだけである。い換觉ると本手術は願舌筋部分切 断術でもある.これにより舌と喉頭が下顎尖端・臨舌筋 付着部を支点として下前方へ回転させて呼吸を楽にする。 手術は局所麻酔で10分内外で終了する.ささらに患者は手 術中より呼吸が良くなったことが実感される12) 14).

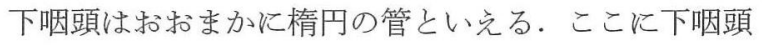
を楕円管と仮定し, 中を流れる気体(空気) は非圧縮性気 体で乱流は発生しない定常流とした場合, 下咽頭の気道 抵抗拉よび気流量の近似解を, Navier-Stroke's の方程 式によって計算することがでさる。すなわち，楕円管に 和ける非圧縮性気体の流量 Qは

$$
Q=\frac{\pi \Delta p}{4 \nu l} \times\left(\frac{a^{3} b^{3}}{a^{2}+b^{2}}\right) \quad \text { (Navier-Stroke's の方程式) }
$$

$\Delta p$ : 圧力差, $l$ : 管の長さ, $\nu$ : 気流の粘性, $a$ : 綎径, $b:$ 横径

上記の式に今回計測の平均値，すなわち術前後の縦径 $12.6 \mathrm{~mm}, 15.6 \mathrm{~mm}$ と管長に最短 H-M $23.3 \mathrm{~mm}, 30.7$ mm を当てはめてみると，管内抵抗比は 0.799 , 気流量 比は1.250となる。

上記の計算により理論的にも CGL 後には下咽頭の気 流の抵抗と流量が増加することが確かめられた。

今までの下咽頭を広げる手術は舌の中央部を切除する か下䫇骨体部を前方へ伸ばすことであった（舌正中切除 術, 下顎骨切り術)。これらの手術は全身麻酔下で手技 が複雑, 出血の問題などがあり時間がかかる。年のら光 術後の管理もかなりの技術を必要とし，適応年齢も限ら れている。ささらに舌正中切除術，下顎骨切り術とも術後 


\section{術前 \\ 術後}

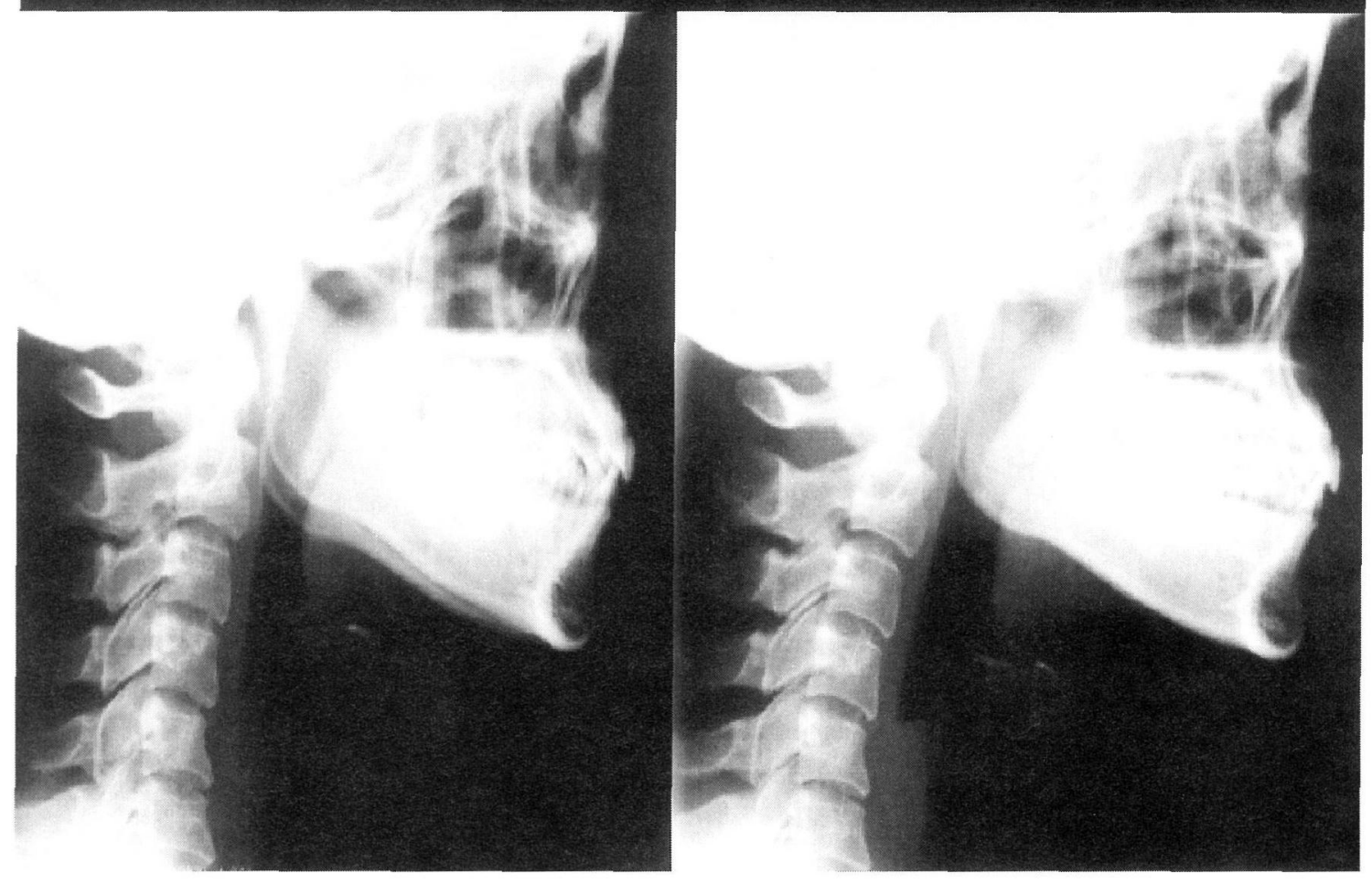

図 3 頭部単純X線写真像 (25歳, 女性) (下咽頭巾が拡大しているのがよくわかる)

の睡眠の改善についての報告はあるが，呼吸機能の改善 については報告されていない15)16).

これに対して CGL は舌正中切除術, 下顎骨切り術な ぞと比較するとはるかに簡単, 安全かつ術後の管理が容 易である。さらにCGLは新生児・乳児から成人まで適 応可能である17) 19).

CGLの術後の変化は呼吸機能についてだけでも, 睡 眠時無呼吸の減少, 呼吸が楽, 肺活量の増加, 一秒率の 増加, 呼吸数の増加などがある.ささらに睡眠についての 術後の変化でも，入眠が早くなった，覚醒が気持らよい， 鼼が減った，昼間眠くなくなった，疲れなくなったなど 自覚症の改善点も非常に多い.

さらにわれわれは視診ならびに䐅頭ファイバース コープによる観察で口腔咽頭が狭いと思われる患者につ いては，睡眠モニターを行っている. 睡眠モニターによ り鼾, 睡眠時無呼吸指数の異常もしくは低酸素状態がみ られた場合はさらに本術式に加穴て ZPP (咽頭Z 拡大術)
を行っている20121)。この操作で上咽頭も拡大して呼吸の しやすさななびに睡眠中の低酸素状態はさらに改善す る.

結論として，呼吸睡眠障害ならびにとれによる諸症状 に対しての第一選択として CGL をすすめる。ささらに症 状に応じてZPPを行ら，CGLならびにZPP は今まで の睡眠・呼吸障害の手術よりも患者に苦痛を与学ず，術 者にとってもストレスの少ない, より効果的な手術とわ れわれは結論する。

$$
\text { まとめ }
$$

CGL による呼吸・睡眠障害さらにはADEL の多彩な 症状の改善についてはすでに本誌ならびに他誌で報告さ れた ${ }^{1)}$. . 今回は1997年 $6 〜 9$ 月に受㡎したADELの 症状を持つ成人 30 名について CGL を行い, 術前後の舌 骨と頭蓋の位置と下咽頭の幅の変化を比較した. 術後に は舌骨と喉頙は下がり，頭蓋はいくぶん上がり，下顎が 
上方に回転していた。また喉頭蓋はより直立し，下咽頭 幅が広くなっていた。CGLは新生児・乳児から成人ま で可能な侵襲のきわめて少ない手術方法である。呼吸・ 睡眠障害, さらには ADEL の多彩な症状に対して積極 的に行われるべきであるとわれわれは考えている.

\section{参考文献}

1) 向井 將, 向井千珈子, 浅岡一之: 先天性舌癒着症 - 喉頭 蓋・喉頭偏位症 一新生児・乳児の呼吸不全一. 耳鼻臨床 $83: 1043 \sim 1065,1990$.

2 ) 向井 將, 向井千珈子, 浅岡一之: 先天性舌癒着症 - 喉頭 蓋・喉頭偏位症 一成人の症状之術前後の呼吸機能の変化一. 耳鼻臨床 $84: 1753 \sim 1761,1991$.

3 ) 向井 將, 向井千珈子, 浅岡一之, 他 : 舌喉頭蓋喉頭矯正 術後の小児の変化. 舌瘉着症研究会会報 $1: 35 \sim 45,1991$.

4) Mukai S, Mukai C and Asaoka K : Congenital ankyloglossia with deviation of the epiglottis and larynx. Ann Otolaryngol 100 supple $153: 1 \sim 20,1991$.

5 ) Mukai S, Mukai C, Nagasugi S, et al : Digit sucking. Lancet 339 : 1545 1546, 1992.

6 ) Mukai S, Mukai C and Asaoka K : Congenital ankyloglossia with deviation of the epiglottis and larynx ; symptoms and respiratory function in adult. Ann Otolaryngol 102 : $620 \sim 624,1993$.

7 ）野瀬橘子, 野瀬善光, 神徳美代子 : 舌癒着症児の特異な症 例(第 1 報) 一睡眠障害と呼吸障害が主症状となった 5 例一. 舌癒着症研究会会報 $6: 44 \sim 55,1996$.

8 ）朝倉光司, 中野勇治, 新谷朋子, 他: 閉塞性睡眠時無呼吸 症候群患者における頭部 X線写真上の顔面頭蓋骨計測値の 検討. 耳喉頭頸 $62: 997 \sim 1001,1990$.

9 ）望月高行, 岡本牧人, 藤川史朗, 他 : 閉塞性睡眠時無呼吸 症候群に打ける軟口蓋低位とセファロメトリの検討. 耳喉 頭頸 $65: 717 \sim 723,1993$.

10）向井 將, 向井千珈子, 荻山光子, 他：ADEL 手術前後
の舌骨，喉頭执よび下䫇の位置の変化. 舌癒着症研究会会 報 8 : 54 57, 1998 .

11) Nitta M, Mukai $S$ and Mukai $C$ : The expansion of the hypopharynx by correction of glosso-larynx. Psychiatry Clin Neurosci 54 : in print, 1999.

12）向井 將, 向井千珈子, 永杉さよ子 : 舌 - 喉頭矯正術の呼 吸に执よぼす影響. 舌癒着症研究会会報 5:1〜9, 1995 .

13）向井 將, 向井千珈子, 永杉さよ子 : 舌 - 喉頭矯正術前後 の児の泣き声の評価. 舌癒着症研究会会報 $5: 44 \sim 54$, 1995.

14）向井 將: 術後の変化について. 舌癒着症研究会会報 5: $82 \sim 92,1995$.

15) Fujita $\mathrm{S}$, Woodson $T$, Clark JL, et al : Laser midline glossectomy as a treatment for obstructive sleep apnea. Laryngoscope $101: 805 \sim 809,1991$.

16) McCarthy, Schreiber J, Karp N, et al : Lengthening the human mandible by gradual distraction. Plast Reconstr Surg $89: 1 \sim 10,1992$.

17）東野逸朗, 永杉さよ子, 荻山光子, 他：舌癒着症手術前後 の身体の柔らかさの変化. 舌癒着症研究会会報 $5: 100$ 101, 1995.

18）野瀬善光, 神徳美代子, 野瀬橘子 : 肥満児に於ける舌喉頭 蓋喉頭偏位症の治療効果 -ADEL 治療群と非治療群との 肥満度比較一. 舌癒着症研究会会報 $6: 1 \sim 7,1996$.

19）向井 將, 向井千功子, 永杉さよ子：泣き声の心理的印象 と音声分析 一第 1 報一. 音声言語医学 $38: 1 \sim 10,1997$.

20) Mukai S, Mukai $C$ and Nitta $M: Z$ Pharyngoplasty. Psychiatry Clin Neurosci 54 : in print, 1999.

21）向井 將, 向井千珈子, 新田暢圭 : 口蓋垂の機能と咽頭 Z 拡大術. 耳鼻臨床 $93: 31 \sim 38,2000$.

原稿受付 : 平成11年 7 月 21 日
原稿採択 : 平成11年 8 月 18 日 急載
別刷請求先 : 新田暢圭
原 $242-0016$ 神奈川県大和市大和南2-8-9
医療法人社団華青会向井診療所

